\title{
PERAN ASEAN DAN NEGARA ANGGOTA ASEAN TERHADAP PERLINDUNGAN PEKERJA MIGRAN
}

(The Role of ASEAN and Its Member Countries in the Protection of Migrant Workers)

\author{
Ade Irawan Taufik \\ Pusat Penelitian dan Pengembangan Sistem Hukum Nasional BPHN \\ Email: adetaufik@bphn.go.id/adeirawantaufik@gmail.com
}

Naskah diterima: 21 Mei 2014; revisi: 20 Agustus 2014; disetujui: 22 Agustus 2014

\begin{abstract}
Abstrak
Isu pekerja migran bukan hal baru, namun masih isu yang aktual, karena masih banyak terjadinya sisi negatif berupa perlakuan yang tidak manusiawi terhadap pekerja migran. Dalam lingkup ASEAN, Indonesia bukan satu-satunya negara pengirim pekerja migran, namun terdapat negara lain dengan negara tujuan yang hampir sama. Permasalahan yang dialami oleh pekerja migran dari negara-negara tersebut pada dasarnya hampir sama dengan yang dialami oleh pekerja migran dari Indonesia. Penelitian ini mengangkat permasalahan, yakni bagaimana peran ASEAN dalam melindungi pekerja migran dan bagaimana kesiapan instrumen hukum Indonesia dan negara-negara anggota ASEAN lainnya dalam melindungi pekerja migran. Dengan menggunakan metode studi tekstual, didapatkan kesimpulan bahwa peran ASEAN dalam melindungi pekerja migran telah tertuang di Piagam ASEAN yang dielaborasikan ke dalam 3 (tiga) pilar Komunitas ASEAN, namun peran tersebut tidak dapat maksimal karena tidak terciptanya konsesus dalam penyusunan instrumen perlindungan hak pekerja migran. Rekomendasi terhadap kebuntuan tersebut adalah dengan membawa dan membahasnya ke dalam pertemuan Dewan Komunitas ASEAN, karena isu tersebut merupakan isu lintas komunitas. Peran ASEAN sangat tergantung kepada upaya masing-masing negara anggota ASEAN dalam merumuskan regulasi dalam hukum nasionalnya masing-masing untuk mengimplemantasikan instrumen ASEAN terkait perlindungan pekerja migran, namun hal ini belum didukung dengan peran negara anggota ASEAN yang relatif rendah dalam komitmen perlindungan pekerja migran.
\end{abstract}

Kata Kunci: pekerja migran, komitmen, perlindungan

\section{Abstract}

The issue of migrant workers is not new, but still the current issue, because there were lots of negative sides in the form of inhumane treatment of migrant workers. Within the scope of ASEAN, Indonesia is not the only sending countries of migrant workers. There were other countries whose sending its migrant workers with similar destinations with Indonesia. Problems faced by migrant workers from those countries are basically the same as experienced by Indonesian migrant workers. This research discusses the problem, namely how ASEAN's role in protecting migrant workers and how's Indonesia and other ASEAN member countries legal instrument readiness to protect migrant workers. By using the method of textual study, it was concluded that the role of ASEAN in the protection of migrant workers has been stated in the ASEAN Charter elaborated into three (3) pillars of the ASEAN Community, nevertheless that roles cannot be maximized for there were no consensus in creating the protection of the rights of migrant workers instruments. Recommendation to the impasse is to bring and discuss it in the ASEAN Community Council meeting, because the issue is a cross-community issue. ASEAN's role in implementing ASEAN instrument on the protection of migrant worker is dependent upon the efforts of each ASEAN member countries in formulating regulations in their respective domestic laws. Nevertheless, their commitments to the protection of migrant workers are relatively poor.

Keywords: migran workers, commitment, protection 


\section{A. Pendahuluan}

Sejalan dengan proses globalisasi, perpindahan manusia dari satu negara ke negara lainnya pun semakin meningkat. Di Asia Tenggara sendiri, migrasi lintas batas negara bukanlah gejala yang baru ada, karena secara historis dan tradisional penduduk yang tinggal di perbatasan antara dua negara sering melakukannya khususnya untuk kegiatan ekonomi. Migrasi ke kota untuk mencari kerja, ke pasar-pasar untuk menjual komoditi, ke daerah pedesaan untuk kerja musiman pertanian, ke wilayah pertambangan dan lainlain, merupakan karakteristik perekonomian dan sejarah Asia Tenggara. Lebih jauh lagi, pada masa kolonialisme telah ada kebijakan untuk memindahkan penduduk dari Jawa ke luar Jawa untuk dipekerjakan di perkebunan-perkebunan dan pertambangan. ${ }^{1}$

Deskripsi tersebut di atas menggambarkan bahwa isu pekerja migran dalam lingkup Indonesia maupun lingkup regional Asia Tenggara bukan sesuatu yang baru, namun juga merupakan isu yang masih aktual. Hal ini karena pekerjaan mempunyai makna yang sangat penting dalam kehidupan manusia sehingga setiap orang membutuhkan pekerjaan. Pekerjaan dapat dimaknai sebagai sumber penghasilan seseorang untuk memenuhi kebutuhan hidup bagi dirinya dan keluarganya. Oleh karena itu hak atas pekerjaan merupakan hak asasi yang melekat pada diri seseorang yang wajib dijunjung tinggi dan dihormati. Makna dan arti pentingnya pekerjaan bagi setiap orang tercermin dalam Pasal 27 ayat (2) Undang-Undang Dasar Negara Republik Indonesia Tahun 1945 (UUD NRI 1945), yang menyatakan bahwa setiap Warga Negara Indonesia berhak atas pekerjaan dan penghidupan yang layak bagi kemanusiaan. ${ }^{2}$

Namun pada kenyataannya, keterbatasan kesempatan kerja di dalam negeri menyebabkan banyaknya warga negara Indonesia atau Tenaga Kerja Indonesia (TKI) yang mencari pekerjaan ke luar negeri. Dari tahun ke tahun jumlah yang bekerja di luar negeri semakin meningkat. Besarnya animo tersebut, disatu sisi mempunyai dampak positif, yaitu mengatasi sebagian masalah pengangguran di dalam negeri, namun mempunyai pula sisi negatif berupa resiko kemungkinan terjadinya perlakuan yang tidak manusiawi terhadap TKI.

Upaya Indonesia untuk melindungi warga negaranya dari resiko perlakuan yang tidak manusiawi adalah dengan melakukan pengaturan dalam berbagai peraturan perundang-undangan dan juga berbagai kebijakan, seperti moratorium pengiriman TKI ke luar negeri.

Namun demikian, praktek penyelenggaraan penempatan TKI ke luar negeri, menyangkut juga hubungan antar negara, khususnya negara tujuan penempatan TKI, sehingga kebijakan dan pengaturan yang ditetapkan oleh Indonesia hanya dapat menjangkau yuridiksi wilayah negara Indonesia, oleh karena itu Pemerintah Indonesia tidak dapat bertindak sendiri, sehingga perlu melibatkan peran serta negara tujuan 
dalam lingkup hubungan bilateral dan juga dalam lingkup regional maupun multilateral, sehingga tercipta kesepahaman bersama yang didasarkan pada prinsip saling membutuhkan secara profesionalisme dan ekonomis dalam hal perlindungan TKI dan juga dalam tataran jaminan perlindungan hak-hak asasi warga negara yang bekerja di luar negeri.

Berdasarkan data dari Badan Nasional Penempatan dan Perlindungan Tenaga Kerja Indonesia (BNP2TKI), tecatat pada periode 20112013 terdapat sebanyak 586.802 (2011); 494.609 (2012); dan 512.618 (2013) TKI yang bekerja di luar negeri, dan dari jumlah tersebut, negara Malaysia menempati urutan pertama sebagai negara tujuan penempatan TKI, dengan jumlah 134.120 (2011), 134.023 (2012) dan 150.236 (2013). Negara-negara atau kota lainnya yang menjadi tujuan penempatan TKI berdasarkan urutan terbesar penerima TKI, yaitu Taiwan, Saudi Arabia, Uni Emirat Arab, Hongkong, Singapura, Qatar, Korea Selatan, Amerika Serikat, dan Brunei Darussalam. ${ }^{3}$

Data dari BNP2TKI menyebutkan bahwa permasalahan yang sering dialami oleh TKI antara lain: Pemutusan Hubungan Kerja (PHK) sepihak, majikan bermasalah, sakit akibat kerja, gaji tidak dibayar; penganiayaan; pelecehan seksual; pekerjaan tidak sesuai Perjanjian Kerja; dokumen tidak lengkap; sakit bawaan; majikan meninggal; kecelakaan kerja; TKI hamil; membawa anak; tidak mampu bekerja; komunikasi tidak lancar dan lain-lain. Meskipun jumlah permasalahan dari tahun 2010-2013 menurun, namun dilihat dari jumlah permasalahan yang besar, yakni 19.741 permasalahan pada tahun 2013, maka hal ini menjadi persoalan serius, karena dari permasalahan-permasalahan tersebut, permasalahan yang paling banyak dialami oleh TKI adalah permasalahan yang timbul karena faktor eksternal diri TKI, yakni PHK sepihak; majikan bermasalah; gaji tidak dibayar; penganiayaan; pelecehan seksual; dan pekerjaan tidak sesuai Perjanjian Kerja. ${ }^{4}$ Namun demikian, jenis pekerjaan dari TKI sendiri juga menjadi faktor atau rentan terjadinya permasalahan, dari tahun ke tahun jumlah TKI yang bekerja di luar negeri didominasi oleh pekerja rumah tangga (domestic worker). Pada tahun 2011 dari total TKI yang ditempatkan sebanyak $45 \%$ adalah domestic worker, dan pada tahun 2012 dan 2013 jumlahnya menurun, namun masih dalam jumlah yang lebih dari angka $30 \% .^{5}$

Permasalahan-permasalahan TKI tersebut, berdasarkan data dari BNP2TKI banyak terjadi di negara-negara dan kota antara lain: Arab Saudi; Uni Emirat Arab; Taiwan; Qatar; Singapura; Oman; Kuwait; Hongkong; Malaysia; Syria; Bahrain; Brunei Darussalam; dan Korea Selatan. Pada tahun 2013, negara Syria merupakan negara yang paling banyak terjadi permasalahan TKI, dengan jumlah 5.054 permasalahan, kemudian negara

3 Sumber data dari Pusat Penelitian dan Pengembangan dan Informasi BNP2TKI dalam Penempatan dan Perlindungan Tenaga Kerja Indonesia Tahun 2013 (www.bnp2tki.go.id, diakses 2 Juni 2014).

4 Angka TKI bermasalah tersebut berdasarkan data Pelayanan TKI Bermasalah di BPK-TKI Selapajang Tangerang. Sumber data dari Pusat Penelitian dan Pengembangan dan Informasi BNP2TKI dalam Penempatan dan Perlindungan Tenaga Kerja Indonesia Tahun 2013 (www.bnp2tki.go.id, diakses 2 Juni 2014).

5 Total jenis jabatan TKI yang bekerja di luar negeri kurang lebih terdapat 600 jenis jabatan. Sumber data dari Pusat Penelitian dan Pengembangan dan Informasi BNP2TKI dalam Penempatan dan Perlindungan Tenaga Kerja Indonesia Tahun 2013 (www.bnp2tki.go.id, diakses 2 Juni 2014). 
Arab Saudi dan Uni Emirat Arab dengan jumlah permasalahan sebanyak 3.769 dan $3.737 .^{6}$

Berdasarkan data tersebut di atas, dalam lingkup regional negara-negara di Asia Tenggara, yakni negara Malaysia, Singapura dan Brunei Darussalam termasuk dalam sepuluh besar negara tujuan penempatan TKI dan juga permasalahan-permasalahan TKI yang terjadi di negara-negara tersebut terbilang relatif banyak, yaitu pada tahun 2013, permasalahan TKI di Singapura sebanyak 478 permasalahan; Malaysia sebanyak 374 permasalahan dan Brunei Darussalam sebanyak 61 permasalahan. ${ }^{7}$

Dalam lingkup regional negara-negara Asia Tenggara, Indonesia bukan merupakan satu-satunya negara pengirim pekerja migran, namun terdapat negara-negara di Asia Tenggara yang juga menjadi negara pengirim pekerja migran, yaitu antara lain Philipina, Thailand, Vietnam, Myanmar, Laos dan Kamboja. Negaranegara pengirim pekerja migran tersebut juga menempatkan sebagian besar pekerja migran ke negara Malaysia, Singapura, Brunei Darussalam dan Thailand. ${ }^{8}$

Permasalahan yang dialami oleh pekerja migran dari negara-negara tersebut pada dasarnya hampir sama dengan yang dialami oleh TKI. Contoh permasalahan yang paling banyak dialami untuk pekerja migran dari Philipina antara lain, gaji yang tidak atau terlambat dibayarkan; gaji dibayarkan lebih rendah dari yang disepakati; paspor ditahan oleh pemberi kerja; jam kerja yang panjang; pelecehan seksual dan fisik; dan lain-lain. ${ }^{9}$

Berdasarkan hal yang telah disebutkan di atas, bahwa permasalahan pekerja migran bukan hanya masalah yang menjadi beban negara pengirim semata, namun juga menjadi beban masalah bagi negara tujuan. Permasalahan dapat saja diselesaikan dalam lingkup bilateral (antara negara pengirim dan negara tujuan), namun akan lebih efektif dan mempunyai kekuatan mengikat yang lebih tinggi bila diselesaikan dalam lingkup regional ASEAN, hal ini karena semua negara anggota ASEAN adalah sebagai negara pengirim maupun negara tujuan pekerja migran, sehingga hal ini mendesak untuk diselesaikan secara bersama oleh semua negara anggota ASEAN.

Oleh karena itu, melihat perkembangan peranan ASEAN dan juga momentum pembentukan Komunitas ASEAN 2015, maka adalah hal yang sangat menarik untuk diteliti bagaimana peranan ASEAN untuk menyepakati bersama dalam menyelesaikan permasalahan pekerja migran dan perlindungan hak pekerja migran. Selain itu perlu diteliti pula bagaimana instrumen hukum Indonesia dan negara-negara anggota ASEAN lainnya dalam melindungi pekerja migran.

\section{Ibid.}

Ibid.

8 Thailand selain menjadi negara pengirim pekerja migran juga menjadi negara tujuan pekerja migran. Lebih lanjut lihat: Bruno Maloni, "Migrant Workers in ASEAN" (makalah disampaikan pada ASEAN Inter-Parliamentary Assembly, Seminar: The Role of Parliamentarians in The Protection and Promotion of the Rights of Migrant Workers in ASEAN, di Phnom Penh Kamboja, tanggal 3-6 April 2011).

9 International Human Right Clinic, The Protection of the Rights of Migrant Domestic Worker in a Country of Origin and a Country of Destination: Case Studies of The Philippines and Kuwait (Washington: International Law and Organizations Program and The Protection Project of The Johns Hopkins University Paul H. Nitze School of Advanced International Studies (SAIS), 2013), hlm. 31. 


\section{B. Metode Penelitian}

Metode penelitian yang digunakan dalam penelitian ini adalah studi tekstual untuk menganalisis peraturan perundang-undangan yang berlaku dan juga kebijakan-kebijakan yang dikeluarkan oleh pemerintah Indonesia, sehingga dari hasil studi tekstual ini didapatkan jawaban terhadap bagaimana kesiapan hukum Indonesia dalam melindungi TKI, selain itu diharapkan juga dapat memberikan jawaban terhadap hal-hal apa saja yang perlu diatur dalam peraturan perundang-undangan. Untuk menjawab permasalahan terkait dengan peran ASEAN dalam melindungi pekerja migran, maka yang dilakukan adalah dengan melakukan studi tekstual terhadap dokumen-dokumen berupa perjanjian-perjanjian internasional dalam lingkup kerjasama regional ASEAN.

Kemudian dalam menjawab hal-hal apa saja yang menjadi permasalahan untuk disepakati bersama dalam forum ASEAN, maka penelitian ini dilakukan dengan mendeskripsikan etnografi persidangan forum-forum ASEAN, yakni terkait pembahasan berbagai traktat, dokumen kebijakan dan deklarasi, yang menghasilkan apa yang disebutnya sebagai transnational consensus building. ${ }^{10}$ Dari studi etnografi tersebut didapati jawaban terhadap hal-hal apa saja yang menjadi permasalahan dan sulit disepakati dalam forum-forum persidangan ASEAN. Permasalahan-permasalahan yang sulit disepakati juga dapat diketahui dari sejauhmana instrumen-instrumen hukum yang dimiliki oleh negara-negara anggota ASEAN dalam mengatur pekerja migran.

\section{Pembahasan}

\section{Peran ASEAN Dalam Melindungi Pekerja Migran}

Merujuk kepada negara pengirim (country of origin) dan negara tujuan (country of destination) pekerja migran serta permasalahan yang dialami oleh pekerja migran, maka terdapat satu persamaan, yaitu bahwa negara-negara tersebut masuk dalam lingkup regional negara-negara Asia Tenggara dan semua negara tersebut adalah anggota Association of South East Asian Nations (ASEAN) atau Perhimpunan Bangsa-Bangsa Asia Tenggara.

Tujuan didirikan ASEAN pada awalnya bertujuan untuk mempercepat pertumbuhan ekonomi, mendorong perdamaian dan stabilitas wilayah, dan membentuk kerja sama di berbagai bidang. Pembentukan ASEAN diawali oleh kesadaran para pemimpin negara di kawasan Asia Tenggara untuk membentuk suatu organisasi kerja sama di kawasan Asia Tenggara yang dilandasi oleh kesadaran perlunya meningkatkan saling pengertian untuk hidup bertetangga secara baik dan membina kerja sama yang bermanfaat di antara negaranegara di kawasan yang terikat oleh pertalian sejarah dan budaya. Atas dasar itu, Menteri Luar Negeri Indonesia, Malaysia, Filipina, Singapura, dan Thailand melakukan berbagai pertemuan konsultatif sehingga disepakati

\footnotetext{
Merry, Sally Engle (2005), Human Rights and Global Legal Pluralism: Reciprocity and Disjuncture dalam BendaBeckmann, Franz, Keebet von Benda-Beckmann, Anne Griffits, Mobile People Mobile Law. Expanding Legal Relations in a Contracting World. USA: Ashgate., dalam Sulistyowati \& Shidarta (eds), Metode Penelitian Hukum: Konstelasi dan Refleksi (Jakarta: Yayasan Obor Indonesia, 2011)
} 
suatu rancangan Deklarasi Bersama (Joint Declaration), yang kemudian deklarasi tersebut ditindaklanjuti dengan melakukan pertemuan dan penandatanganan Deklarasi ASEAN (The ASEAN Declaration) atau Deklarasi Bangkok (Bangkok Declaration) pada tanggal 8 Agustus 1967, bertempat di Bangkok, Thailand. ${ }^{11}$

Perkembangan organisasi ASEAN yang menunjukan kemajuan yang cukup signifikan di bidang politik dan ekonomi, mendorong negaranegara di Asia Tenggara lainnya bergabung menjadi anggota ASEAN, yakni Brunei Darussalam, ${ }^{12}$ Vietnam, ${ }^{13}$ Laos, Myanmar ${ }^{14}$ dan Kamboja, ${ }^{15}$ sehingga anggotanya menjadi 10 (sepuluh) negara. Perkembangan ASEAN tersebut juga memasuki tahap penting, yaitu menjelang abad ke-21, ASEAN sepakat untuk mengembangkan suatu kawasan yang terintegrasi dengan membentuk suatu komunitas negara-negara Asia Tenggara yang terbuka, damai, stabil dan sejahtera, saling peduli, dan diikat bersama dalam kemitraan yang dinamis di tahun 2020, yaitu dengan disepakatinya pembentukan Komunitas ASEAN (ASEAN Community). ${ }^{16}$

Perkembangan ASEAN yang signifikan dan telah memasuki tahap penting, yang ditandai dengan disepakatinya pembentukan Komunitas ASEAN (ASEAN Community), yang memiliki konsekuensi adanya komitmen diantara negara anggota ASEAN dalam mempererat integrasi masyarakat ASEAN yang lebih terbuka, damai, stabil dan sejahtera, saling peduli, selain itu berakibat juga terhadap penyesuaian cara pandang keterbukaan dalam menyikapi perkembangan dunia. ${ }^{17}$ Cara pandang ini dapat diartikan sebagai bagaimana negara anggota ASEAN dalam menyikapi dan menyelesaikan isu atau permasalahan yang terjadi antara sesama anggota ASEAN. Sehingga pembentukan Komunitas ASEAN dapat dijadikan momentum dalam menyelesaikan permasalahan- pekerja migran.

${ }_{11}$ Kementerian Luar Negeri, ASEAN Selayang Pandang, Edisi ke-19 (Jakarta: Kementerian Luar Negeri, 2010), hlm. 2-3.

12 Brunei Darussalam resmi menjadi anggota ke-6 ASEAN pada tanggal 7 Januari 1984, dalam Sidang Khusus Menteri-Menteri Luar Negeri ASEAN (ASEAN Ministerial Meeting/AMM) di Jakarta, Indonesia.

13 Vietnam resmi menjadi anggota ke-7 ASEAN pada tanggal 29-30 Juli 1995, dalam Pertemuan para Menteri Luar Negeri ASEAN ke-28 di Bandar Seri Begawan, Brunei Darussalam.

14 Laos dan Myanmar resmi menjadi anggota ke-8 dan ke-9 ASEAN tanggal 23-28 Juli 1997, dalam pada Pertemuan para Menteri Luar Negeri ASEAN ke-30 di Subang Jaya, Malaysia.

15 Kamboja resmi menjadi anggota ke-10 ASEAN dalam Upacara Khusus Penerimaan pada tanggal 30 April 1999 di Hanoi, Vietnam.

16 Kesepakatan tersebut dituangkan dalam Visi ASEAN 2020 yang ditetapkan oleh para Kepala Negara/ Pemerintahan ASEAN pada Konferensi Tingkat Tinggi (KTT) ASEAN di Kuala Lumpur tanggal 15 Desember 1997. Selanjutnya, untuk merealisasikan harapan tersebut, ASEAN mengesahkan Bali Concord II pada KTT ASEAN ke-9 di Bali tahun 2003 yang menyepakati pembentukan Komunitas ASEAN pada tahun 2020. Namun upaya kesepakatan pembentukan Komunitas ASEAN semakin kuat dengan ditandatanganinya Deklarasi Cebu mengenai Percepatan Pembentukan Komunitas ASEAN pada tahun 2015 (Cebu Declaration on the Acceleration of the Establishment of an ASEAN Community by 2015) oleh para Pemimpin ASEAN pada KTT ke-12 ASEAN di Cebu, Filipina, tanggal 13 Januari 2007. Dengan ditandatanganinya Deklarasi tersebut, para Pemimpin ASEAN menyepakati percepatan pembentukan Komunitas ASEAN dari tahun 2020 menjadi tahun 2015. Lebih lanjut lihat ASEAN Selayang Pandang, Op.Cit., hlm. 4-5.

17 Direktorat Jenderal Kerja Sama ASEAN Kementerian Luar Negeri, Ayo Kita Kenali ASEAN (Jakarta: Kementerian Luar Negeri, 2011), hlm. 22. 
Perkembangan ASEAN yang signifikan juga terwujud dengan ditandatanganinya Piagam ASEAN (ASEAN Charter) pada KTT ke-13 ASEAN di Singapura bulan November 2007. ${ }^{18}$ Piagam ASEAN mengubah ASEAN dari organisasi yang longgar (loose association) menjadi organisasi yang berdasarkan hukum (rules based organization) dan menjadi subjek hukum (legal personality).

Piagam ASEAN sebagai dokumen konstitusional, memuat norma-norma, penegasan tentang kedaulatan, hak-hak dan kewajiban-kewajiban dan sejumlah kekuasaan-kekuasaan dalam proses legislatif, eksekutif dan yudisial. Piagam ASEAN menegaskan bahwa negara-negara anggota mampu mengadopsi nilai-nilai demokrasi dan penghormatan akan HAM termasuk hakhak sipil dan politik. Piagam ASEAN sebagai dokumen konstitusional memuat beberapa elemen penting antara lain: 1) Pernyataan secara tegas bahwa ASEAN adalah organisasi internasional yang memiliki kepribadian hukum internasional, dengan demikian ASEAN mampu melaksanakan hak dan kewajiban di tingkat internasional; 2) Pernyataan secara tegas bahwa ASEAN memiliki tujuan-tujuan, fungsi-fungsi dan kewenangan-kewenangan seperti organisasi internasional lainnya, artinya, Piagam ini akan mengubah ASEAN menjadi into a rules based organization; 3) Pembentukan mekanisme legislatif, the rule-making mechanism/organs and procedures di dalam ASEAN; 4) Pembentukan sebuah mekanisme eksekutif atau organ yang bertugas untuk melaksanakan serta memonitoring pelaksanaan peraturan-peraturan dan keputusan-keputusan organisasi; 5) Pembentukan mekanisme judicial dan quasi judicial yang berfungsi untuk menginterpretasikan dan melaksanakan setiap peraturan dan keputusan yang dikeluarkan oleh ASEAN; 6) Secara langsung Piagam ASEAN akan membantu untuk mendorong dan memperkuat penataan terhadap perjanjian-perjanjian ASEAN oleh negara anggotanya dan secara tidak langsung dapat meningkatkan sense of region di antara pemerintah ASEAN. ${ }^{19}$

Perkembangan-perkembangan ASEAN yang signifikan tersebut seharusnya berkorelasi positif terhadap upaya dan peran ASEAN dalam mengatur dan menyelesaikan permasalahanpermasalahan yang timbul di antara negara anggota ASEAN. Sehingga hal dasar yang perlu dikritisi adalah apakah Piagam ASEAN memiliki peran dalam mengakomodir kepentingan buruh migran?

Migrant Care berpendapat bahwa di dalam Piagam ASEAN ternyata memperkecualikan pekerja upah murah (mayoritas buruh migran) dalam kebebasan mobilitas tenaga kerja di ASEAN dan memperkecualikan aspek-aspek perlindungannya. Namun apa yang menjadi dasar 'pengecualian' yang disampaikan oleh

18 Piagam ASEAN mulai berlaku pada tanggal 15 Desember 2008 setelah semua negara anggota ASEAN menyampaikan ratifikasi. Indonesia telah meratifikasi Piagam ASEAN melalui Undang-Undang Nomor 38 Tahun 2008 tentang Pengesahan Piagam Perhimpunan Bangsa-Bangsa Asia Tenggara (Charter of The Association of Southeast Asian Nations). Lebih lanjut lihat Kementerian Luar Negeri, ASEAN Selayang Pandang, Op.Cit., hlm. 5

19 Liona Nanang Supriatna, "Piagam ASEAN : Menuju Pemajuan Dan Perlindungan HAM di Asia Tenggara" Jurnal Hukum Internasional, Vol. 5, No. 3 (April 2008): 557-558. 
Migrant Care tidak jelas disebutkan. ${ }^{20}$ Pendapat serupa juga disampaikan oleh Wahyu Susilo, yang menilai Piagam ASEAN tidak dapat memberikan perlindungan terhadap buruh migran, karena tidak ada satupun pernyataan eksplisit dalam piagam tersebut yang mengakui peran dan hak buruh migran sebagai penggerak ekonomi di ASEAN, hal ini berarti ASEAN tidak memiliki komitmen politik untuk memberikan perlindungan pada hak buruh migran. Selain itu, isi Piagam ASEAN bersifat diskriminatif terhadap hak buruh migran di sektor informal seperti pembantu rumah tangga. Piagam ini hanya memuat perlindungan pada pekerja kerah putih yang terlatih, sehingga merugikan buruh migran, terutama TKI yang sebagian besar bergerak disektor informal. ${ }^{21}$

Penulis memiliki pendapat yang berbeda dengan Migrant Care tersebut, karena apabila merujuk pada tujuan ASEAN sebagaimana tersebut dalam Pasal 1 Piagam ASEAN, maka pengakuan terhadap eksistensi pekerja migran telah diakomodir di dalam Pasal 1 angka (5) Piagam ASEAN, ${ }^{22}$ meskipun pasal ini sebenarnya dalam konteks terkait dengan penciptaan ekonomi yang berdasarkan pasar tunggal dan basis produksi yang dilakukan melalui perdagangan dan investasi. Oleh karena itu, faktor pekerja migran dalam konteks ini dapat dimaknai sebagai salah satu subjek dalam Jalu lintas jasa.

Pasal 1 angka (5) Piagam ASEAN ini bertujuan untuk memfasilitasi pergerakan pekerja migran. Pekerja migran yang difasilitasi dalam konteks pasal ini tidak hanya para pelaku usaha atau pekerja profesional yang terdidik dan terlatih, namun juga dapat dimaknai pekerja migran dalam arti buruh migran atau pekerja informal. Merujuk pada teks Pasal 1 angka (5) ini, maka ada beberapa subjek yang difasilitasi dalam lalu lintas jasa, yakni: a) pelaku usaha (business persons); b) pekerja profesional (professionals) ; dan c) pekerja berbakat dan buruh (talents and labour). Pengakuan dan fasilitasi juga harus diberikan kepada pekerja migran dalam hal ini buruh migran, karena sejalan dengan tujuan ASEAN lainnya sebagaimana tersebut dalam Pasal 1 angka (13) Piagam ASEAN, yakni berorientasi kepada rakyat dan yang didalamnya seluruh lapisan masyarakat didorong untuk berpartisipasi dalam, dan memperoleh manfaat dari, proses integrasi dan pembangunan Komunitas ASEAN.

Senada dengan pendapat penulis, Pemerintah berpendapat bahwa Pasal 1 Piagam ASEAN menyebutkan secara tegas bahwa pencapaian single market (pasar tunggal) dilakukan melalui kebebasan pelaku usaha, 
pekerja profesional, pekerja berbakat, dan buruh. Dengan demikian Pasal 1 Piagam ASEAN juga memberikan kesempatan yang sama bagi pekerja profesional dan buruh. Berdasarkan Pasal 1 ayat (5) Piagam ASEAN bahwa pembentukan single market dimaksudkan untuk memajukan perdagangan, investasi dan mendorong lalu-lintas pelaku usaha, pekerja profesional, pekerja berbakat serta buruh. Pembentukan single market juga diabdikan kepada upaya mengurangi kemiskinan dan mempersempit kesenjangan pembangunan (Pasal 1 ayat (6) Piagam ASEAN). ${ }^{23}$

Namun demikian, oleh karena Piagam ASEAN merupakan norma dasar, maka hal yang terpenting adalah mengimplementasikan tujuan-tujuan ASEAN sebagaimana tersebut dalam Pasal 1 Piagam ASEAN, termasuk perlindungan buruh migran ke dalam ranah yang lebih konkrit. Pengimplementasian tujuantujuan tersebut harus sejalan dengan prinsip ASEAN, sebagaimana tersebut dalam Pasal 2 Piagam ASEAN, yakni antara lain: ASEAN dan negara-negara anggotanya menegaskan kembali dan memegang teguh prinsip-prinsip dasar yang tertuang dalam deklarasi-deklarasi, persetujuan-persetujuan, konvensi-konvensi, concords, traktat-traktat, dan instrumen ASEAN lainnya; ${ }^{24}$ prinsip adannya komitmen bersama dan tanggung jawab kolektif dalam meningkatkan perdamaian, keamanan dan kemakmuran di kawasan; ${ }^{25}$ prinsip ditingkatkannya konsultasi mengenai hal-hal yang secara serius memengaruhi kepentingan bersama ASEAN; ${ }^{26}$ dan menghormati kebebasan fundamental, pemajuan dan perlindungan hak asasi manusia, dan pemajuan keadilan sosial. ${ }^{27}$

Terkait dengan implementasi tujuan ASEAN dalam perlindungan buruh migran ke dalam ranah yang lebih konkrit tersebut, maka hal yang dikaji adalah apakah pembentukan Komunitas ASEAN, serta deklarasi-deklarasi, persetujuanpersetujuan, concords, traktat-traktat dan instrumen ASEAN lainnya memiliki peran dalam mengatur dan menyelesaikan permasalahan pekerja migran?

Komunitas ASEAN terdiri dari 3 (tiga) pilar, yakni Komunitas Politik-Keamanan ASEAN (ASEAN Political-Security Community/APSC), Komunitas Ekonomi ASEAN (ASEAN Economic Community/AEC), dan Komunitas Sosial Budaya ASEAN (ASEAN Socio-Cultural Community/ ASCC). Isu atau permasalahan pekerja migran merupakan isu multi dimensi, karena terdapat unsur perlindungan dan bantuan hukum, unsur ekonomi dan sosial budaya, oleh karena itu di dalam pembentukan Komunitas ASEAN, isu pekerja migran melibatkan ketiga pilar tersebut, karena ketiga pilar tersebut membahas isu pekerja migran berdasarkan perspektif masingmasing pilar.

23 Lebih lanjut lihat salinan Putusan Mahkamah Konstitusi Nomor 33/PUU-IX/2011, perkara Permohonan Pengujian Undang-Undang Nomor 38 Tahun 2008 tentang Pengesahan Charter of the Association of Southeast Asian Nations (Piagam Perhimpunan Bangsa-Bangsa Asia Tenggara) terhadap Undang-Undang Dasar Negara Republik Indonesia Tahun 1945).

24. Pasal 2 ayat (1) Piagam ASEAN.

25 Pasal 2 ayat (2) huruf (b) Piagam ASEAN.

26 Pasal 2 ayat (2) huruf (g) Piagam ASEAN.

27 Pasal 2 ayat (2) huruf (i) Piagam ASEAN. 


\section{a. Pilar Komunitas Politik-Keamanan ASEAN}

Komunitas Politik Keamanan ASEAN dibentuk dengan tujuan mempercepat kerja sama politik keamanan di ASEAN untuk mewujudkan perdamaian di kawasan, termasuk dengan masyarakat internasional. Sebagai pedoman dalam mencapai tujuan dari Komunitas PolitikKeamanan ASEAN tersebut maka disusun Cetak Biru Komunitas Politik-Keamanan ASEAN (ASEAN Political-Security Community Blueprint). Cetak Biru Komunitas Politik-Keamanan ASEAN terdiri atas 3 (tiga) karakteristik, 11 (sebelas) elemen, dan 137 tindakan. Tiga karakteristik tersebut adalah: i) Komunitas Berbasis Aturan dengan Nilai dan Norma Bersama (A Rulesbased Community of Shared Values and Norms), terdiri dari 2 (dua) elemen dan dijabarkan dalam 58 tindakan; ii) Sebuah Wilayah Terpadu, Damai dan Tangguh dengan Tanggung Jawab Bersama untuk Keamanan Menyeluruh ( $A$ Cohesive, Peaceful, Stable and Resilient Region with Shared Responsibility for Comprehensive Security), terbagi dalam 6 (enam) elemen dan 71 tindakan; dan iii) Kawasan yang Dinamis dan Berpandangan Keluar dalam Dunia yang Semakin Terintegrasi dan Saling Bergantung (A Dynamic and Outward Looking Region in an Increasingly Integrated and Interdependent World) yang dijabarkan dalam 3 (tiga) elemen dan 8 tindakan. ${ }^{28}$

Ketiga karakteristik serta elemen dan tindakan tersebut kemudian diimplementasikan oleh Badan-Badan Sektoral di ASEAN dan kerjasama-kerjasama dalam kerangka Komunitas Politik-Kemanan ASEAN.

Dalam karakteristik Komunitas Berbasis Aturan dengan Nilai dan Norma Bersama, di dalam bentuk elemen Promosi dan Perlindungan Hak Asasi manusia disepakati suatu tindakan (action) untuk melakukan kerjasama secara erat dalam badan-badan sektoral untuk pengembangan instrumen ASEAN tentang perlindungan dan promosi hak-hak pekerja migran. ${ }^{29}$

Proses mengimplementasikan terhadap perlindungan dan promosi hak-hak pekerja migran ke dalam instrumen ASEAN dalam konteks Komunitas Politik Keamanan ASEAN salah satunya melalui Deklarasi Hak Asasi ManusiaASEANyang telah disahkan berdasarkan Pernyataan Phnom Penh mengenai Pengesahan Deklarasi Hak Asasi Manusia ASEAN (Phnom Penh Statement on the Adoption of The ASEAN Human Rights Declaration/AHRD). ${ }^{30}$ Di dalam bagian prinsip umum Deklarasi HAM ASEAN dinyatakan bahwa "Hak-hak perempuan, anakanak, orang lanjut usia, penyandang disabilitas, pekerja migran, serta kelompok rentan dan terpinggirkan merupakan bagian dari hak asasi manusia dan kebebasan dasar yang melekat, menyatu, dan tidak terpisahkan".

Deklarasi HAM ASEAN tersebut merupakan hasil penyusunan dari Komisi Antar Pemerintah ASEAN tentang HAM (ASEAN Inter-Governmental Commission on Human Rights/AICHR). Keberadaan AICHR diakui mempunyai peran penting sebagai institusi penanggung jawab

Kementerian Luar Negeri, ASEAN Selayang Pandang, Op.Cit., hlm. 21.

29 Section A.1.5. ASEAN Political-Security Community Blueprint. Lebih lanjut lihat ASEAN Secretariat, ASEAN PoliticalSecurity Community Blueprint (Jakarta: ASEAN Secretariat, 2009), hlm. 5.

30 Dibuat di Phnom Penh, Kamboja, pada tanggal 18 November 2012. 
utama bagi pemajuan dan pelindungan hak asasi manusia di ASEAN, yang berkontribusi bagi terbentuknya Komunitas ASEAN yang berorientasi kepada masyarakat dan sebagai sarana untuk pembangunan sosial dan keadilan yang progresif, pemenuhan martabat manusia dan pencapaian kualitas kehidupan yang lebih baik untuk masyarakat ASEAN. ${ }^{31}$

Selain itu, dalam upaya untuk menegaskan kembali terhadap pengakuan perlindungan terhadap buruh migran terutama perempuan dan anak-anak, maka telah diadopsi "The Declaration on the Elimination of Violence against Women and Elimination of Violence against Children in ASEAN", pada 9 Oktober 2013 di Brunei Darussalam. Kemudian pada tanggal dan tempat yang sama telah pula diadopsi "ASEAN Declaration on Strengthening Social Protection", yang memuat prinsip bahwa semua orang, terutama mereka yang miskin, berisiko, penyandang cacat, orang tua, putus usia sekolah, anak-anak, pekerja migran, dan kelompok rentan lainnya, berhak untuk memiliki akses yang adil terhadap perlindungan sosial yang merupakan hak dasar manusia dan didasarkan pada kebutuhan dasar, pendekatan siklus hidup dan mencakup layanan penting yang diperlukan.

Namun, upaya ASEANdalammempromosikan dan melindungi pekerja migran melalui pengadopsian deklarasi-deklarasi tersebut bukan merupakan suatu upaya dan peran yang optimal dan final. Tantangan kemudian adalah memastikan pelaksanaan yang efektif dari deklarasi-deklarasi tersebut dan memasukan nilai-nilai yang terkadung dalam deklarasideklarasi tersebut ke dalam mekanisme nasional di setiap negara anggota ASEAN. ${ }^{32}$

Finalisasi negosiasi isu-isu perlindungan hak asasi manusia, seperti promosi dan perlindungan hak-hak pekerja migran, tetap menjadi salah satu tantangan penting yang memerlukan upaya lanjutan dan kolektif oleh negara-negara anggota ASEAN untuk mempercepat proses. Kemajuan untuk mengembangkan instrumen hukum ASEAN untuk mempromosikan dan melindungi hak-hak pekerja migran harus diselesaikan sebelum pembentukan Komunitas ASEAN pada akhir 2015.

Memasukan nilai-nilai yang terkandung dalam deklarasi-deklarasi tersebut ke dalam mekanisme nasional di setiap negara anggota ASEAN merupakan keniscayaan demi efektifnya pelaksanaan dari deklarasi tersebut, namun dalam konteks perlindungan bagi pekerja migran belum banyak yang dilakukan oleh negara-negara anggota ASEAN untuk melakukan tindakan dalam mekanisme hukum nasional negara anggota ASEAN berupa melakukan ratifikasi terhadap perjanjian internasional yang terkait dengan pekerja migran.

\section{b. Pilar Komunitas Ekonomi ASEAN}

Cetak Biru Komunitas Ekonomi ASEAN (ASEAN Economic Community Blueprint/AEC Blueprint) yang ditandatangani bersamaan dengan penandatangan Piagam ASEAN, dimaksudkan untuk mencapai Visi ASEAN

Lebih lanjut lihat konsideran Pernyataan Phnom Penh mengenai Pengesahan Deklarasi Hak Asasi Manusia ASEAN.

32 Lebih lanjut lihat konsideran Pernyataan Phnom Penh mengenai Pengesahan Deklarasi Hak Asasi Manusia ASEAN. 
2020, yaitu menjadikan kawasan ASEAN yang stabil, makmur, dan sangat kompetitif dengan pembangunan ekonomi yang merata, dan mengurangi kemiskinan dan kesenjangan sosialekonomi. ${ }^{33}$

Cetak Biru Komunitas Ekonomi ASEAN memiliki 4 (empat) karakteristik utama, yakni untuk mewujudkan ASEAN sebagai: 1) Pasar tunggal dan basis produksi, dengan 5 (lima) elemen utama yaitu: (i) aliran bebas barang; (ii) aliran bebas jasa; (iii) aliran bebas investasi; (iv) aliran bebas tenaga kerja terampil; dan (iv) aliran modal yang lebih bebas. Di samping kelima elemen tersebut, pasar tunggal dan basis produksi juga mencakup 2 (dua) komponen penting lainnya, yaitu Sektor Integrasi Prioritas (Sectors Integration Priority/PIS) dan kerjasama di bidang pangan, pertanian, dan kehutanan;

2) Kawasan ekonomi yang berdaya saing tinggi, dengan 6 (enam) elemen utama yaitu: (i) kebijakan persaingan usaha; (ii) perlindungan konsumen; (iii) hak atas kekayaan intelektual (HKI); (iv) pembangunan infrastruktur; (v) perpajakan; dan (vi) e-commerce; 3) Kawasan dengan pembangunan ekonomi yang setara, dengan 2 (dua) elemen utama yaitu: (i) pengembangan usaha kecil dan menengah (UKM); dan (ii) inisiatif integrasi ASEAN (Inisiative for ASEAN Integration/IAI); 4) Kawasan yang terintegrasi ke dalam ekonomi global, dengan 2 (dua) elemen utama yaitu: (i) pendekatan terpadu terhadap ekonomi di luar kawasan, dan (ii) peningkatan partisipasi dalam jaringan pasokan global. ${ }^{34}$
Merujuk pada karakteristik AEC Blueprint tersebut di atas, maka salah satu langkah yang dilakukan untuk membentuk ASEAN sebagai suatu pasar tunggal dan basis produksi serta menjadikan ASEAN lebih dinamis dan kompetitif adalah dengan mempermudah pergerakan para pelaku usaha tenaga kerja terampil dan berbakat. ${ }^{35} \mathrm{Di}$ dalam karakteristik Pasar Tunggal dan Basis Produksi terdapat elemen Aliran bebas tenaga kerja terampil, yaitu dalam rangka mobilisasi yang terkelola serta memfasilitasi masuknya tenaga kerja yang terlibat dalam perdagangan barang, jasa dan investasi sesuai dengan peraturan yang berlaku di negara penerimaan, ASEAN tengah mengupayakan tindakan: i) memfasilitasi penerbitan visa dan employment pass bagi tenaga kerja terampil ASEAN yang bekerja di sektor-sektor yang berhubungan dengan perdagangan dan investasi antar-negara ASEAN; ii) mengupayakan harmonisasi dan standardisasi, untuk memfasilitasi pergerakan tenaga kerja di kawasan; iii) mempererat kerja sama di antara anggota ASEAN University Network (AUN) untuk meningkatkan mobilitas mahasiswa dan staf pengajar di kawasan; dan juga mengembangkan kompetensi dasar dan kualifikasi untuk pekerjaan dan keterampilan pelatihan yang dibutuhkan dalam sektor jasa prioritas; dan iv) memperkuat kemampuan riset setiap negara anggota ASEAN dalam rangka meningkatkan keterampilan, penempatan kerja dan pengembangan jejaring informasi pasar tenaga kerja di antara negara-negara ASEAN.

ASEAN, ASEAN Economic Community Blueprint (Jakarta: ASEAN Secretariat, 2008), hlm. 5.

34 Kementerian Luar Negeri, ASEAN Selayang Pandang, Op.Cit, hlm. 54. Lihat juga ASEAN, ASEAN Economic Community Blueprint (Jakarta: ASEAN Secretariat, 2008), hlm. 6.

35 ASEAN, ASEAN Economic Community Blueprint (Jakarta: ASEAN Secretariat, 2008), hlm. 5. 
Merujuk pada karakteristik Pasar tunggal dan basis produksi yang di dalamnya hanya terdapat elemen aliran bebas tenaga kerja terampil, maka terdapat inkonsistensi pengakuan terhadap pekerja buruh migran, hal ini terlihat dengan tidak ditemukannya pengakuan eksistensi pekerja migran dari sektor buruh dan informal dalam karakteristik tersebut maupun karakteristik lainnya dalam ASEAN Economic Community Blueprint.

Tidak adanya pengakuan eksistensi pekerja migran tersebut juga menciptakan ketidakkonsistenan terhadap tujuan ASEAN sebagaimana tersebut dalam Pasal 1 angka (5) Piagam ASEAN yang memfasilitasi pergerakan pekerja migran, yang tidak hanya pekerja profesional yang terdidik dan terlatih, namun juga pekerja migran dalam arti buruh migran atau pekerja informal, sehingga hal ini juga tidak sejalan dengan Pasal 1 angka (13) Piagam ASEAN, yakni berorientasi kepada rakyat dan yang didalamnya seluruh lapisan masyarakat didorong untuk berpartisipasi dalam, dan memperoleh manfaat dari, proses integrasi dan pembangunan Komunitas ASEAN. Begitu juga dengan pendapat Pemerintah yang menyatakan bahwa dalam konteks pencapaian single market (pasar tunggal) dilakukan melalui kebebasan pelaku usaha, pekerja profesional, pekerja berbakat, dan buruh, yang dimaksudkan untuk memajukan perdagangan, investasi dan mendorong lalu-lintas pelaku usaha, pekerja profesional, pekerja berbakat serta buruh.

Tidak diakuinya eksistensi pekerja buruh migran, menunjukan bahwa pekerja buruh migran baru dianggap sebagai objek dan bukan subjek dalam konteks komunitas ekonomi ASEAN, padahal telah diakui secara umum kontribusi pekerja buruh migran terhadap aspek ekonomi ditempat negara tujuan maupun negara asal sangat signifikan. Untuk itu perlu direformulasikan kembali eksistensi pekerja buruh migran dalam konteks pilar komunitas ekonomi ASEAN, sehingga dapat disejajarkan dengan tenaga kerja terampil atau pekerja migran terampil dân juga bertujuan untuk memfasilitasi dan mengembangkan kompetensi dasar dari pekerja buruh migran.

\section{c. Komunitas Sosial Budaya ASEAN}

Tujuan utama dari Komunitas Sosial Budaya ASEAN (ASEAN Socio-Cultural Community/ASCC) adalah untuk memberikan kontribusi untuk mewujudkan Komunitas ASEAN yang berdasar pada pendekatan kemasyarakatan (peoplecentered approach) dan tanggung jawab sosial untuk mencapai solidaritas dan persatuan abadi di antara bangsa-bangsa dan rakyat ASEAN dengan membangun masyarakat yang saling peduli dan berbagi. ${ }^{36}$ Kerja sama di bidang sosialbudaya menjadi salah satu titik tolak utama untuk meningkatkan integrasi ASEAN melalui terciptanya "a caring and sharing community", yaitu sebuah masyarakat ASEAN yang saling peduli dan berbagi. Kerja sama sosial budaya mencakup kerja sama di bidang kepemudaan, perempuan, perlindungan anak, kepegawaian, penerangan, kebudayaan, pendidikan, ilmu pengetahuan dan teknologi, lingkungan hidup, penanggulangan bencana alam, kesehatan, pembangunan sosial, pengentasan kemiskinan, ketenagakerjaan, dan Yayasan ASEAN. ${ }^{37}$

36 ASEAN, ASEAN Socio-Cultural Community Blueprint (Jakarta: ASEAN Secretariat, 2009), hlm. 1.

37 Kementerian Luar Negeri, ASEAN Selayang Pandang, Op.Cit, hlm. 122. 
Kerja sama di bidang ketenagakerjaan ASEAN diarahkan pada upaya untuk menggalang sikap bersama (common position) ASEAN dalam menanggulangi isu-isu ketenagakerjaan, antara lain perbaikan lingkungan kerja dan upaya perlindungan dan pemajuan (protection and promotion) hak tenaga kerja migran (migrant worker). Kerjasama dalam ketenagakerjaan merupakan bagian dari kerjasama sosial budaya dalam pilar Komunitas Sosial Budaya ASEAN, sehingga yang perlu dikritisi adalah apakah kerjasama ketenagakerjaan dalam pilar ini berperan dalam menanggulangi permasalahan pekerja migran?

Untuk mewujudkan terbentuknya Komunitas Sosial Budaya ASEAN, ASEAN telah menyusun Cetak Biru Komunitas Sosial Budaya ASEAN (ASEAN Socio Cultural Community Blueprint) yang disahkan pada KTT ASEAN ke-14 di Cha-am Hua Hin, Thailand tanggal 1 Maret 2009. Di dalam blueprint tersebut, ASCC memiliki karakteristik ketahanan budaya regional, kepatuhan terhadap prinsip-prinsip yang disepakati, semangat kerja sama, tanggung jawab kolektif, untuk mempromosikan pembangunan manusia dan sosial, menghormati kebebasan dasar, kesetaraan gender, promosi dan perlindungan hak asasi manusia dan promosi sosial keadilan. Berdasarkan hal tersebut terdapat 6 (enam) karakteristik utama dalam ASCC, yaitu: (a) Pembangunan Manusia; (b) Perlindungan dan Kesejahteraan Sosial; (c) Keadilan Sosial dan Hak-hak; (d) Memastikan Kelestarian Lingkungan Hidup (e) Membangun Identitas ASEAN; dan (f) Mempersempit kesenjangan Pembangunan. ${ }^{38}$
Di dalam karakteristik Keadilan Sosial dan Hak-hak, ASEAN berkomitmen mempromosikan keadilan sosial dan pengarusutamaan hak-hak rakyat ke dalam kebijakan dan semua bidang kehidupan, termasuk hak-hak dan kesejahteraan kelompok yang kurang beruntung, rentan dan marjinal seperti perempuan, anak-anak, orang tua, penyandang cacat dan pekerja migran. Sehingga dalam konteks karakteristik tersebut tindakan yang dilakukan melalui program Perlindungan dan Promosi Hak Pekerja Migran. Tujuan dari program tersebut yaitu memastikan kebijakan migrasi yang adil dan komprehensif dan perlindungan yang memadai bagi semua pekerja migran sesuai dengan hukum, peraturan dan kebijakan masing-masing negara anggota ASEAN serta melaksanakan Deklarasi ASEAN tentang Perlindungan dan Promosi Hak-Hak Pekerja Migran. ${ }^{39}$

Untuk memastikan tujuan dari program tersebut terwujud, maka tindakan-tindakan yang dilakukan, yaitu: ${ }^{40}$ Pertama, Membentuk Komite ASEAN tentang Pelaksanaan Deklarasi ASEAN tentang Perlindungan dan Promosi HakHak Pekerja Migran di bawah naungan SLOM ${ }^{41}$ untuk melaksanakan ketentuan Deklarasi dan bekerja menuju pengembangan instrumen ASEAN tentang perlindungan dan promosi hakhak pekerja migran; Kedua, Institusionalisasi dan mengadakan secara teratur Forum ASEAN pada Buruh Migran sebagai platform untuk diskusi berbasis luas tentang isu-isu perburuhan migran di bawah naungan Komite, yang bertanggung jawab kepada SLOM; Ketiga, Mempromosikan perlindungan gaji yang adil dan tepat upah

ASEAN, ASEAN Socio-Cultural Community Blueprint (Jakarta: ASEAN Secretariat, 2009), hlm. 1.

ASEAN, ASEAN Socio-Cultural Community Blueprint (Jakarta: ASEAN Secretariat, 2009), hlm. 12.

Ibid., hlm. 13.

41 Pertemuan tingkat Pejabat Senior Ketenagakerjaan (Senior Labour Officials Meeting/SLOM). 
dan akses yang memadai terhadap kerja dan kondisi kehidupan yang layak bagi pekerja migran dan menyediakan akses yang memadai terhadap sistem hukum dan peradilan negara penerima pekerja migran, bagi pekerja migran yang mungkin menjadi korban diskriminasi, pelecehan, eksploitasi, kekerasan; Keempat, Mengintensifkan upaya untuk melindungi hak asasi manusia, memajukan kesejahteraan dan menjunjung tinggi martabat manusia pekerja migran oleh, antara lain, memfasilitasi pelaksanaan fungsi konsuler kepada pihak berwenang, konsuler atau diplomatik dari negara asal pekerja migran ketika ditangkap atau dimasukkan ke penjara atau tahanan atau ditahan dengan cara lain, berdasarkan hukum dan peraturan negara menerima dan sesuai dengan konvensi Wina dan Hubungan Konsuler; Kelima, Memfasilitasi berbagi data mengenai hal-hal yang berkaitan dengan pekerja migran untuk tujuan meningkatkan kebijakan dan program tentang pekerja migran di kedua negara pengirim dan penerima; Keenam, Memperkuat kebijakan dan prosedur di negara pengirim untuk memfasilitasi aspek pekerja migrasi, termasuk rekrutmen, persiapan untuk penyebaran luar negeri dan perlindungan TKI di luar negeri serta pemulangan dan reintegrasi ke negara-negara asal; Ketujuh, Memfasilitasi akses ke sumber daya dan obat melalui informasi, pelatihan dan pendidikan, akses terhadap keadilan, dan pelayanan kesejahteraan sosial yang sesuai dan sesuai dengan undangundang dan negara penerima, asalkan mereka memenuhi persyaratan berdasarkan hukum yang berlaku, peraturan, dan kebijakan negara mengatakan, perjanjian bilateral dan perjanjian multilateral; Kedelapan, Membangun dan mempromosikan praktek hukum dari negara pengirim untuk mengatur perekrutan buruh migran dan mengadopsi mekanisme untuk menghilangkan malpraktek perekrutan melalui kontrak legal dan valid, regulasi, dan akreditasi agen perekrutan dan pengusaha, dan daftar hitam dari lalai / lembaga yang melanggar hukum; dan Kesembilan, Mempromosikan pembangunan kapasitas dengan berbagi informasi, praktek-praktek terbaik serta peluang dan tantangan dalam kaitannya dengan perlindungan dan promosi hak-hak pekerja migran dan kesejahteraan.

Mencermati tindakan-tindakan yang gariskan dalam konteks program Perlindungan dan Promosi Hak Pekerja Migran dalam Cetak Biru Komunitas Sosial Budaya tersebut, maka sebenarnya tindakan-tindakan tersebut sebagian besar mengadopsi substansi dari Deklarasi ASEAN mengenai Perlindungan dan Pemajuan Hak Pekerja Migran (Declaration on the Protection and Promotion of the Rights of Migrant Workers).

Dalam bidang pekerja migran, KTT ASEAN Ke-12 di Cebu, tanggal 13 Januari 2007, telah menghasilkan Deklarasi ASEAN mengenai Perlindungan dan Pemajuan Hak Pekerja Migran (Declaration on the Protection and Promotion of the Rights of Migrant Workers) yang memuat kewajiban negara pengirim, negara penerima maupun ASEAN dalam memberikan perlindungan dan pemajuan hak pekerja migran. Sebagai tindak lanjut, pada Pertemuan ke-40 AMM di Manila, tanggal 30 Juli 2007, telah dibentuk Komite ASEAN mengenai Implementasi Deklarasi ASEAN mengenai Perlindungan dan Pemajuan Hak-Hak Tenaga Migran (ASEAN Committee on the Implementation of the Declaration on the Protection and Promotion of the Rights of Migrant Workers/ACMW), sebagai penanggung jawab pelaksana ASEAN dalam mengkoordinasikan implementasi Deklarasi 
serta memfasilitasi pengembangan instrumen perlindungan dan pemajuan hak-hak pekerja migran, yang saat ini sedang disusun oleh Tim Penyusun ACMW (ACMW-Drafting Team). Sementara pada pertemuan SLOM Ke-5, tanggal 15-16 Mei 2007, telah dibentuk Forum Tenaga Migran (Forum on Migrant Workers) sebagai forum pertemuan seluruh pemilik kepentingan di bidang tenaga migran. ${ }^{42}$

Salah satu agenda utama ACMW adalah menyusun ASEAN Instrument on the Protection and Promotion of the Rights of Migrant Workers. Instrumen tersebut dimaksudkan agar ASEAN akan memiliki landasan hukum yang kuat dalam menangani isu-isu perlindungan dan pemajuan hak-hak pekerja migran, yang sesuai dengan visi ASEAN: "a caring and sharing community". Namun pembahasan instrumen tersebut belum dapat diselesaikan karena terdapat pandangan yang berbeda antara negara penerima dan negara pengirim tenaga migran. ${ }^{43}$

Semenjak dibentuknya ACMW pada tahun 2007 sampai dengan saat ini, keberadaan instrumen perlindungan dan pemajuan hak-hak pekerja migran belum dapat disepakati oleh negara anggota ASEAN. Belum disepakatinya instrumen tersebut disebabkan antara lain: pertama, masih diperdebatkannya mengenai status instrumen perlindungan itu, apakah nantinya mengikat (legally binding) atau tidak untuk negara ASEAN; kedua, pembahasan cakupan "anggota keluarga" pekerja migran; dan ketiga, masih berpolemik mengenai perlindungan pekerja migran yang tak terdokumentasi. ${ }^{44}$ Selain itu terdapat permasalahan yang sulit untuk disepakati, yaitu terkait definisi dan ruang lingkup dari pekerja migran. ${ }^{45}$

Bahwa dasar pembentukan instrumen perlindungan dan pemajuan hak-hak pekerja migran merupakan amanat dari Deklarasi ASEAN mengenai Perlindungan dan Pemajuan Hak Pekerja Migran. Pada hakekatnya 'deklarasi' merupakan suatu pernyataan politik (political statement) yang tidak mengikat hak dan kewajiban negara anggota maupun organisasi atas dasar hukum/konstitusi, sehingga deklarasi dapat dikatakan hanya mengikat secara moral atau sebagai bentuk soft law dari perjanjian internasional. Hal ini lah juga mendasari ASEAN dari yang didirikan berdasarkan 'deklarasi' sehingga ASEAN pada saat itu adalah organisasi yang longgar (loose association) menjadi terbentuknya Piagam ASEAN, yang menjadikan ASEAN sebagai organisasi yang berdasarkan hukum (rules based organization) dan menjadi subjek hukum (legal personality). Namun demikian 'deklarasi' yang merupakan perjanjian internasional, mempunyai kekuatan mengikat seperti halnya "treaty" atau "convention", tetapi karena bentuk dan strukturnya, tidak praktis dan belum memadai dan tidak komprehensif, maka perlu suatu kerangka kerja hukum melalui pembuatan perjanjian-perjanjian internasional dalam kerangka dan sistem ASEAN. ${ }^{46}$ 
Atas dasar tersebut, maka Instrumen perlindungan dan pemajuan hak-hak pekerja migran sebagai amanat deklarasi Deklarasi ASEAN mengenai Perlindungan dan Pemajuan Hak Pekerja Migran seharusnya merupakan suatu kerangka hukum yang seharusnya memiliki kekuatan mengikat terhadap negara anggota ASEAN.

Permasalahan terkait cakupan perlindungan terhadap "anggota keluarga" pekerja migran dan juga perlindungan pekerja migran yang tidak terdokumentasi yang sampai saat ini belum mencapai kesepakatan, menurut Penulis, permasalahan tersebut akan mengalami kesulitan untuk disepakati, hal ini karena Deklarasi ASEAN mengenai Perlindungan dan Pemajuan Hak Pekerja Migran yang mengamanatkan untuk disusunnya instrumen perlindungan dan pemajuan hak-hak pekerja migran, di butir ke-4 bagian Prinsip-Prinsip Umum-nya (General Principles) secara tegas menyatakan bahwa "Nothing in the present Declaration shall be interpreted as implying the regularisation of the situation of migrant workers who are undocumented". Prinsip tersebut jelas telah menegaskan bahwa maksud dari deklarasi tersebut tidak dimaksudkan untuk mengatur pekerja migran yang tidak berdokumen, sehingga instrumen yang akan disusun tidak boleh mengatur terkait dengan undocumented workers, kecuali terjadi konsesus untuk mengaturnya. Begitu pula dengan permasalahan cakupan perlindungan terhadap "anggota keluarga" akan mengalami kesulitan untuk disepakati, hal ini dikarenakan perlindungan hak dan martabat pekerja migran dan keluarganya tergantung kepada regulasi dan kebijakan dari masing-masing negara penerima, ketentuan ini ditemukan di dalam bagian butir ke-3 Prinsip-Prinsip Umum Deklarasi ASEAN mengenai Perlindungan dan Pemajuan Hak Pekerja Migran menyatakan bahwa: "The receiving states and the sending states shall take into account the fundamental rights and dignity of migrant workers and family members already residing with them without undermining the application by the receiving states of their laws, regulations and policies".

Bahwa sebenarnya cakupan perlindungan bagi "anggota keluarga" pekerja migran dan juga pekerja migran yang tak terdokumentasi merupakan hal-hal dasar yang mendapatkan perlindungan sebagaimana yang telah diatur di dalam Konvensi Internasional tentang Perlindungan Hak Semua Buruh Migran dan Anggota Keluarganya (International Convention on the Protection of the Rights of All Migrant Workers and Member of Their Families). ${ }^{47}$

Namun permasalahannya, belum semua negara-negara anggota ASEAN telah meratifikasi konvensi tersebut. Negara anggota ASEAN yang sudah meratifikasi baru Indonesia dan Philipina, sedangkan Kamboja baru menandatangani dan belum meratifikasi. ${ }^{48}$ Sangat sedikitnya negara anggota ASEAN yang telah meratifikasi konvensi tersebut, menjadi salah satu sebab sulitnya

\footnotetext{
7 Disahkan melalui Resolusi Majelis Umum PBB 45/158 tanggal 18 Desember 1990.

48 Indonesia telah menandatangani United Nations on the Protection of the Rights of All Migrant Workers and Member of Their Families pada tanggal 22 September 2004 dan telah diratifikasi melalui Undang-Undang Nomor 6 Tahun 2012. Philipina telah menandatangani konvensi tersebut pada tanggal 15 November 1993 dan telah diratifikasi pada tanggal 5 Juli 1995, sedangkan Kamboja hanya baru menandatangi konvensi tersebut pada tanggal 27 September 2004, lihat United Nations Treaty Collection, https:/
} 
tercipta konsensus di dalam penyusunan intrumen perlindungan dan pemajuan hak-hak pekerja migran. Namun demikian, terdapat alternatif terhadap kebuntuan konsensus penyusunan instrumen perlindungan HAM, yakni Indonesia dapat secara paralel dapat melakukan pendekatan secara bilateral dengan masing-masing negara penerima, sehingga akan lebih efektif dalam menyepakati penyelesaian permasalahan pekerja migran.

\section{Kesiapan Instrumen Hukum Indonesia dan Negara-Negara Anggota ASEAN Lainnya Dalam Melindungi Pekerja Migran}

Sebagaimana telah dideskripsikan di atas, bahwa finalisasi negosiasi isu-isu promosi dan perlindungan hak-hak pekerja migran, tetap menjadi salah satu tantangan penting yang memerlukan upaya lanjutan dan kolektif oleh negara-negara anggota ASEAN untuk mempercepat proses, selain itu memasukan prinsip-prinsip yang terkandung dalam deklarasi-deklarasi tersebut ke dalam mekanisme nasional di setiap negara anggota ASEAN juga merupakan keniscayaan demi efektifnya pelaksanaan dari deklarasi tersebut. Sehingga yang perlu dikritisi adalah sejauhmana komitmen dari negara-negara anggota ASEAN untuk melakukan tindakan ke dalam mekanisme hukum nasional masing-masing negara anggota ASEAN dalam mengatur pekerja migran dalam regulasi dan kebijakan dari negara anggota ASEAN tersebut.

Apabila indikator komitmen negara anggota ASEAN dalam upaya untuk melindungi pekerja migran diindikasikan dari jumlah negara anggota ASEAN yang meratifikasi Konvensi Internasional tentang Perlindungan Hak Semua Buruh Migran dan Anggota Keluarganya dan juga konvensi-konvensi lainnya yang secara tidak langsung terkait dengan pekerja migran, maka dapat dinilai bahwa negara-negara anggota ASEAN memiliki komitmen yang rendah dalam perlindungan pekerja migran. Hal ini dapat terlihat dari tidak adanya negara angggota ASEAN yang merupakan negara penerima pekerja migran yang meratifikasi konvensi tersebut, begitu pula negara anggota ASEAN yang menjadi negara pengirim pekerja migran, hanya baru Philipina dan Indonesia yang telah meratifikasinya.

Rendahnya komitmen negara anggota ASEAN terhadap perlindungan pekerja migran juga dapat diindikasikan dari rendahnya ratifikasi terhadap perjanjian internasional yang secara tidak langsung terkait dengan perlindungan pekerja migran. Mengingat tingginya angka pekerja migran Indonesia yang menjadi pekerja rumah tangga (domestic workers) sudah saatnya seharusnya Indonesia meratifikasi Konvensi International Labour Organization (ILO) No. 189 tentang Kerja Layak Pekerja Rumah Tangga (Convention concerning Decent Work for Domestic Worker, 2011). Konvensi Pekerja Rumah Tangga tersebut hanya baru diratifikasi oleh negara Philipina, sedangkan negara anggota ASEAN lainya belum meratifikasi. Konvensi ILO No. 189 merupakan instrumen penting untuk standar perlindungan pekerja rumah tangga di dalam dan luar negeri. ${ }^{49}$ 
Mengingat konsep perlindungan pekerja migran tidak terlepas dari konteks perlindungan hak asasi manusia, maka indikator komitmen peran negara anggota ASEAN terhadap perlindungan pekerja migran juga tidak terlepas ratifikasi konvensi-konvensi dan instrumen internasional lainnya dalam konteks hak asasi manusia. Konvensi-konvensi dan instrumen internasional dalam bidang hak asasi manusia yang secara tidak langsung mengatur perlindungan pekerja migran, dapat dilihat dalam tabel di bawah ini:

Tabel 1: Instrumen Internasional Terkait Perlindungan Buruh

\begin{tabular}{|c|c|c|c|c|c|c|c|c|c|c|}
\hline \multirow{2}{*}{ Instrumen Internasional } & \multicolumn{10}{|c|}{ Negara Anggota ASEAN Yang Telah Meratifikasi } \\
\hline & Brunei & Kamboja & Indonesia & Laos & Malaysia & Myanmar & Philipina & Singapura & Thailand & Vietnam \\
\hline $\begin{array}{l}\text { Konvensi Internasional tentang } \\
\text { Penghapusan Segala Bentuk } \\
\text { Diskriminasi Rasial (CERD) }\end{array}$ & & $P$ & $P$ & $P$ & & & & & $P$ & $P$ \\
\hline $\begin{array}{l}\text { Kovenan Internasional tentang Hak- } \\
\text { hak Sipil dan Politik (ICCPR) }\end{array}$ & & $P$ & $P$ & $P$ & & & $\mathrm{P}$ & & $P$ & $P$ \\
\hline $\begin{array}{l}\text { Protokol Opsional pada Kovenan } \\
\text { Internasional tentang Hak-hak Sipil } \\
\text { dan Politik (ICCPR) }\end{array}$ & & $P$ & & & & & $P$ & & & \\
\hline $\begin{array}{l}\text { Kovenan Internasional tentang } \\
\text { Hak Ekonomi, Sosial dan Budaya } \\
\text { (ICESCR) }\end{array}$ & & $P$ & $P$ & & & & $P$ & & $P$ & $P$ \\
\hline $\begin{array}{l}\text { Protokol Opsional pada Kovenan } \\
\text { Internasional tentang Hak Ekonomi, } \\
\text { Sosial dan Budaya (ICESCR) }\end{array}$ & & & & & & & & & & \\
\hline $\begin{array}{l}\text { Konvensi tentang Penghapusan } \\
\text { Segala Bentuk Diskriminasi } \\
\text { terhadap Perempuan (CEDAW) }\end{array}$ & $\mathrm{P}$ & & & $P$ & $P$ & $P$ & $P$ & $\mathrm{P}$ & $P$ & $P$ \\
\hline $\begin{array}{l}\text { Protokol Opsional pada Konvensi } \\
\text { tentang Penghapusan Segala } \\
\text { Bentuk Diskriminasi terhadap } \\
\text { Perempuan (CEDAW) }\end{array}$ & & & $P$ & & & & $P$ & & $P$ & \\
\hline $\begin{array}{l}\text { Konvensi Menentang Penyiksaan } \\
\text { dan Perlakuan atau Penghukuman } \\
\text { Lain yang Kejam, Tidak manusiawi } \\
\text { atau Merendahkan Martabat } \\
\text { Manusia (CAT) }\end{array}$ & & $P$ & $P$ & & & & $P$ & & $P$ & \\
\hline Konvensi tentang Hak Anak & $\mathrm{P}$ & $\mathrm{P}$ & $\mathrm{P}$ & $\mathrm{P}$ & $\mathrm{P}$ & $P$ & $\mathrm{P}$ & $\mathrm{P}$ & $P$ & $P$ \\
\hline $\begin{array}{l}\text { Protokol untuk Mencegah, } \\
\text { Menghapus dan Menghukum } \\
\text { Perdagangan Orang, Khususnya } \\
\text { Perempuan dan Anak-Anak }\end{array}$ & & $P$ & $P$ & $P$ & $P$ & $P$ & $P$ & & $P$ & \\
\hline $\begin{array}{l}\text { Protokol Melawan Penyelundupan } \\
\text { Buruh Migran melalui Darat, Laut } \\
\text { dan Udara }\end{array}$ & & $P$ & $P$ & $P$ & & $P$ & $P$ & & $P$ & \\
\hline
\end{tabular}

Sumber: diolah oleh Penulis dari Human Rights Resource Centre, Rule of Law untuk Hak Asasi Manusia di Kawasan ASEAN: Studi Data Awal (Jakarta: HRRC, 2011). 
Merujuk pada Tabel 1 di atas, apabila diklasifikasikan berdasarkan negara penerima dan negara pengirim pekerja migran, maka komitmen peran negara penerima terhadap perlindung hak asasi manusi sangat rendah, hal ini dapat terlihat dari instrumen-instrumen internasional yang telah diratifikasi oleh negara penerima pekerja migran.

Deskripsi di atas juga mengindikasikan bahwa upaya negara anggota ASEAN dalam perlindungan pekerja migran masih jauh dari yang diharapkan, karena ratifikasi baru dianggap sebagai upaya awal untuk melindungi pekerja migran, karena selanjutnya masih ada tindakan lanjutan yang harus dilakukan, yaitu menyusun instrumen regulasi dan mengharmonisasikan regulasi untuk mengimplemetasikan dari ratifikasi tersebut.

Dalam lingkup Indonesia, telah banyak peran yang dilakukan oleh Indonesia dalam melindungi TKI. Selain telah meratifikasi Konvensi Internasional tentang Perlindungan Hak Semua Buruh Migran dan Anggota Keluarganya, saat ini telah dibahas Rancangan Undang-Undang (RUU) tentang Perlindungan Pekerja Indonesia di Luar Negeri sebagai pengganti dari Undang-Undang Nomor 39 Tahun 2004 tentang Penempatan dan Perlindungan Tenaga Kerja Indonesia di Luar Negeri. ${ }^{50}$ RUU ini dimaksudkan untuk mengganti Undang-Undang Nomor 39 Tahun 2004, karena undang-undang tersebut mengandung ketidakpastian hukum, pembagian tugas dan wewenang yang tidak proporsional antara pemerintah dan swasta sehingga menimbulkan ketidakefektifan hukum, dan sistem perlindungan dan pengelolaan yang kurang berpihak kepada Pekerja Indonesia di Luar Negeri. ${ }^{51}$

Selain itu, Indonesia saat ini juga sedang menyusun Rancangan Undang-Undang tentang Perlindungan Pekerja Rumah Tangga. ${ }^{52}$ RUU ini dimaksudkan untuk menjamin pemenuhan hak-hak dasar dan kesejahteraan pekerja rumah tangga beserta keluarganya. ${ }^{53}$ Namun sebaiknya proses penyusunan RUU ini didahului terlebih dahulu dengan meratifikasi Konvensi International Labour Organization (ILO) No. 189 tentang Kerja Layak Pekerja Rumah Tangga, sehingga konvensi tersebut menjadi landasan dalam proses penyusunan RUU Perlindungan Pekerja Rumah Tangga dan juga penyusunan Rancangan Undang-Undang tentang Perlindungan Pekerja Indonesia di Luar Negeri, mengingat tingginya angka pekerja buruh migran yang bekerja di sektor domestic workers.

Merujuk regulasi dan kebijakan yang berlaku dari masing-masing negara anggota ASEAN terkait dengan perlindungan pekerja migran, dan apabila diklasifikasikan berdasarkan negara penerima dan negara pengirim pekerja migran, maka terlihat minimya pengaturan terkait perlindungan pekerja migran. Regulasi-regulasi

50 Rancangan Undang-Undang tentang Perlindungan Pekerja Rumah Tangga sebagai RUU prioritas nomor 38 dalam Program Legislasi Nasional Rancangan Undang-Undang Prioritas Tahun 2014 (Keputusan DPR RI Nomor 03A/ DPR RI/II/2013-2014.

51 Lihat bagian Penjelasan Umum Rancangan Undang-Undang tentang Perlindungan Pekerja Indonesia di Luar Negeri.

52 Rancangan Undang-Undang tentang Perlindungan Pekerja Indonesia di Luar Negeri sebagai RUU prioritas nomor 22 dalam Program Legislasi Nasional Rancangan Undang-Undang Prioritas Tahun 2014 (Keputusan DPR RI Nomor 03A/DPR RI/II/2013-2014.

53 Lihat konsideran bagian menimbang dari Rancangan Rancangan Undang-Undang tentang Perlindungan Pekerja Rumah Tangga. 
yang diberlakukan di negara penerima baru sebatas mengatur bagaimana pekerja migran tersebut adalah pekerja migran yang resmi dan melalui agen atau jalur yang resmi.

Tabel 2 di bawah ini menunjukkan bahwa Singapura dan Thailand telah secara khusus mengatur pekerja migran adalah. Singapura, misalnya pada tahun 2011, telah mengamandemen Undang-Undang tentang AgenAgen Ketenagakerjaan (Employment Agencies
Act), yang bertujuan untuk meningkatkan peraturan pemerintah mengenai agen-agen ketenagakerjaan. Denda yang dikenakan atas bekerjanya agen-agen tenaga kerja ilegal telah meningkat secara tajam. ${ }^{54}$ Perhatian yang serius terhadap domestic workers (pekerja rumah tangga) telah diperlihatkan oleh Brunei Darussalam dengan memberlakukan Employment (Domestic Workers) Regulations.

Tabel 2: Regulasi dan Kebijakan Di Negara Penerima Pekerja Migran

\begin{tabular}{|c|c|}
\hline Negara & Peraturan dan Kebijakan \\
\hline $\begin{array}{l}\text { Brunei } \\
\text { Darussalam }\end{array}$ & $\begin{array}{l}\text { - Workmen's Compensation Act, (Cap. 74) (Law) } \\
\text { - Trafficking and Smuggling of Persons Order, } 2004 \text { (government order) } \\
\text { - Employment (Domestic Workers) Regulations, } 2009 \\
\text { - Employment Order } 2009 \text { (law) }\end{array}$ \\
\hline Malaysia & $\begin{array}{l}\text { - Industrial Relations Act of } 1967 \text { (Act 177) } \\
\text { - Immigration Act 1959/63 (Act 155) \& Regulations and Orders \& Passports Act } 1966 \text { (Act 150) } \\
\text { - Immigration Act 1959/63 (Act 155) \& Regulations and Orders \& Passports Act } 1966 \text { (Act 150) } \\
\text { - Occupational Safety and Health Act } 1994 \text { (Act 514), Regulations \& Orders } \\
\text { - Employment Act } 1955 \text { (Act 265) } \\
\text { - Anti-Trafficking in Persons Act } 2007 \\
\text { - Employment Information Act } 1953 \\
\text { - Private Employment Agencies Act } 1981 \text { (Act } 246 \\
\text { - Wages Councils Act } 1947 \text { (Act 195) }\end{array}$ \\
\hline Singapura & $\begin{array}{l}\text { - Employment Agencies Act } \\
\text { - Employment of Foreign Manpower Act (Chapter 91A) } \\
\text { - Employment Act (Chapter 91) } \\
\text { - Passport Act }\end{array}$ \\
\hline Thailand & $\begin{array}{l}\text { - Working of Alien Act, B.E.2551 (2008)1 } \\
\text { - Ministry of Labour Regulation on the Exemption of a Work Permit Fee for Myanmar Workers } \\
\text { who complete and pass the Nationality Verification Process and are permitted to Stay Legally } \\
\text { in Thailand B.E.2552 (2009) } \\
\text { - Ministry of Labour Regulation on the Exemption of a Work Permit Fee for Laotian and } \\
\text { Cambodian Workers who complete and pass the nationality Verification Process and are } \\
\text { permitted to Stay Legally in Thailand, B.E.2550 (2007) } \\
\text { - Ministerial Regulation concerning application for and issuing of work permits and declaring } \\
\text { employment of foreign workers B.E. } 2554 \text { (2011) }\end{array}$ \\
\hline
\end{tabular}

Sumber: diolah kembali oleh Penulis dari ASEAN, Repository Matrix of Legislations and Policies on Migrant Workers of ASEAN Member State (Jakarta, ASEAN Secretariat, 2012).

54 Human Rights Resource Centre, Rule of Law untuk Hak Asasi Manusia di Kawasan ASEAN: Studi Data Awal (Jakarta: HRRC, 2011), hlm. 264. 
Apabila merujuk pada Tabel 3 di bawah ini, maka Indonesia dan Philipina sebagai negara pengirim pekerja migran relatif telah komprehensif dalam melindungi pekerja migran mereka baik dalam tahap sebelum penempatan dan pada masa penempatan di luar negeri.

Tabel 3: Regulasi dan Kebijakan Di Negara Pengirim Pekerja Migran

\begin{tabular}{|c|c|}
\hline Negara & Peraturan dan Kebijakan \\
\hline Kamboja & $\begin{array}{l}\text { - Cambodian National Consultation on the Protection and Promotion of the Rights of Migrant } \\
\text { Workers } \\
\text { - Labor Law of Cambodia (law) } \\
\text { - Prakas (Ministerial Regulation) on Education of HIV/AIDS, Safe Migration and Labor Rights for } \\
\text { Cambodian Migrant Workers Abroad } \\
\text { - Prakas on the creation of a labour migratin taskforce (Ministerial regulation) } \\
\text { - Policy on Labour Migration for Cambodia }\end{array}$ \\
\hline Laos & $\begin{array}{l}\text { - Labor Law (Amended) } \\
\text { - Law on the Protection of the Rights and Interests of Children } \\
\text { - Law on Development and Protection of Women }\end{array}$ \\
\hline Myanmar & $\begin{array}{l}\text { - Law Relating to Overseas Employment } \\
\text { - Law Amending the Myanmar Immigration (Emergency Provisions) Act, } 1947 \\
\text { - The Anti Trafficking in Persons Law } \\
\text { - The Burma Immigration (Emergency Provisions) Act, } 1947\end{array}$ \\
\hline Philipina & $\begin{array}{l}\text { - Executive Order No. 392: Amending Executive Order No. } 182 \text { dated February } 14,2003 \text { entitled } \\
\text { "Transferring the Medicare Functions of the Overseas Workers Welfare Administration to the } \\
\text { Philippine Health Insurance Corporation" } \\
\text { - Migrant Workers and Overseas Filipinos Act of } 1995 \\
\text { - Executive Order No. 220: Creating An Executive Council to Suppress Trafficking in Persons, } \\
\text { Particularly Women and Children } \\
\text { - Memorandum Circular No. 14: Requirements for the Verification, Registration, and Documentation } \\
\text { of Overseas Household Service Workers and Selected Skills } \\
\text { - Memorandum Circular No. 10: Pre-Qualification of Filipino Household Service Worker } \\
\text { - Memorandum Circular No. 11: Transition Period to Implement the Governing Board Resolution } \\
\text { Affecting Household Service Workers, Low/semiskilled Female Workers and Applicants for New } \\
\text { License using HSWs as their New Market } \\
\text { - Special Protection of Children Against Child Abuse, Exploitation and Discrimination Act (Republic } \\
\text { Act) } \\
\text { - Inter-Country Adoption Act of 1995Overseas Workers'Investment (OWI) Fund Act } \\
\text { - An Act to Strengthen the Regulatory Functions of the Philippine Overseas Employment } \\
\text { Administration (POEA), Amending for this Purpose Republic Act No. 8042, otherwise known as } \\
\text { the "Migrant Workers and Overseas Filipinos Act of } 1995 \text { (republic Act) } \\
\text { - Executive Order No. 759: Creating a Task Force Against Illegal Recruitment } \\
\text { - Executive Order No. 446: Tasking the Secretary of Labor and Employment to Oversee and } \\
\text { Coordinate the Implementation of Various Initiatives for Overseas Filipino Workers (OFWs) } \\
\text { - Executive Order No. 195: Providing a Medical Care Program to Filipino Overseas Contract Workers } \\
\text { and Their Dependents and Prescribing the Mechanism Therefor } \\
\text { - Presidential DecreeNo. 1694: Organization and Administration of the Welfare Fund for Overseas } \\
\text { Workers }\end{array}$ \\
\hline
\end{tabular}




\begin{tabular}{|c|c|}
\hline Vietnam & $\begin{array}{l}\text { - Official Dispatch No.129/TBCP dated } 17 \text { April } 2009 \text { of the Office of Government informing } \\
\text { conclusion of the Prime Minister on Foreign Workers in Viet Nam } \\
\text { - Official Dispatch No.129/TBCP dated } 17 \text { April } 2009 \text { of the Office of Government informing } \\
\text { conclusion of the Prime Minister on Foreign Workers in Viet Nam } \\
\text { - Decision No. 18/2007/QDBLDTBXH of July 18, 2007, promulgating the Program on providing } \\
\text { laborers with necessary knowledge before they go to work abroad } \\
\text { - Decision No. 19/2007/QDBLDTBXH of July 18,2007, promulgating the Regulation on organizational } \\
\text { structures of sections sending laborers to work abroad and sections specialized in providing; } \\
\text { laborers with necessary knowledge before they go to work abroad } \\
\text { - Decision No. 20/2007/QDBLDTBXH of August 2, 2007, promulgating certificate of necessary } \\
\text { knowledge provided to laborers before they go to work abroad } \\
\text { - Joint Circular No. 08/2007/TTLT-BLDTBXH-BTP of July } 11,2007 \text {, guiding in detail a number of } \\
\text { matters regarding the contents of guarantee contracts for laborers going abroad to work under } \\
\text { contracts and liquidation of guarantee contracts } \\
\text { - Joint Circular of Ministry of Labour-War Invalids and Social Welfare and the Ministry of Finance } \\
\text { No.10/2004/TTLTBLDTBXH-BTC dated } 16 \text { December } 2004 \text { providing the implementation of } \\
\text { medical check-up and medical report for Vietnamese workers seeking for oversea employment } \\
\text { - Joint Circular of Ministry of Labour-War Invalids and Social Welfare and Ministry of Finance } \\
\text { No.16/2007/TTLT-BLDTBXHBTC dated 04 September } 2007 \text { providing instructions regarding agency } \\
\text { and service fees in sending Vietnamese workers for oversea employment } \\
\text { - Joint Circular of Ministry of Labour-War Invalids and Social Welfare and the State Bank of Viet } \\
\text { Nam No.17/2007/TTLTBLDTBXH-NHNNVN dated } 04 \text { September } 2007 \text { providing the management } \\
\text { and use of deposit of recruitment agencies and deposit of guest workers } \\
\text { - Law on Vietnamese Guest Workers }\end{array}$ \\
\hline
\end{tabular}

Sumber: diolah kembali oleh Penulis dari ASEAN, Repository Matrix of Legislations and Policies on Migrant Workers of ASEAN Member State (Jakarta, ASEAN Secretariat, 2012).

Merujuk deskripsi tersebut di atas, maka baik negara penerima dan negara pengirim pekerja migran telah terdapat instrumen regulasi dari negara masing dalam mengatur pekerja migran, namun pengaturan tersebut tetap pada perspektif kepentingan masing-masing negara, yang seharusnya adalah dalam regulasi tersebut, baik negara penerima maupun negara pengirim terdapat suatu kesamaan prinsip-prinsip universal dalam perlindungan pekerja migran. Penyebab perbedaan prinsip tersebut salah satunya adalah tidak diratifikasinya Konvensi Internasional tentang Perlindungan Hak Semua Buruh Migran dan Anggota Keluarganya dan instrumen internasional lainnya oleh semua negara anggota ASEAN.

\section{Penutup}

Bahwa peran ASEAN dalam melindungi pekerja migran tertuang di Piagam ASEAN yang dielaborasikan ke dalam 3 (tiga) pilar Komunitas ASEAN. Piagam ASEAN dalam konteks pembentukan single market memberikan kesempatan yang sama bagi pekerja profesional dan buruh untuk memajukan perdagangan, investasi dan mendorong lalu-lintas pelaku usaha, pekerja profesional, pekerja berbakat serta buruh. Namun demikian, dalam konteks pilar Komunitas ASEAN terjadi inkonsistensi terhadap pengakuan eksistensi pekerja buruh migran, karena dalam Pilar Komunitas Ekonomi ASEAN hanya memfasilitasi pergerakan pekerja profesional yang terdidik dan terlatih saja. Tidak diakuinya eksistensi pekerja buruh migran, menunjukan bahwa pekerja buruh migran baru 
dianggap sebagai objek dan bukan subjek dalam konteks komunitas ekonomi ASEAN, padahal telah diakui secara umum kontribusi pekerja buruh migran terhadap aspek ekonomi ditempat negara tujuan maupun negara asal sangat signifikan. Untuk itu perlu direformulasikan kembali eksistensi pekerja buruh migran dalam konteks pilar komunitas ekonomi ASEAN, sehingga dapat disejajarkan dengan tenaga kerja terampil atau pekerja migran terampil dan juga bertujuan untuk memfasilitasi dan mengembangkan kompetensi dasar dari pekerja buruh migran.

Namun demikian, peran ASEAN dalam perlindungan pekerja migran telah ditunjukan di dalam pilar Komunitas Politik-Keamanan ASEAN dan pilar Komunitas Sosial Budaya ASEAN. Dalam lingkup Komunitas Politik-Keamanan ASEAN, proses implementasi terhadap perlindungan dan promosi hak-hak pekerja migran ke dalam instrumen ASEAN salah satunya melalui Deklarasi Hak Asasi Manusia ASEAN. Sedangkan dalam pilar Komunitas Sosial-Budaya ASEAN telah disepakati Deklarasi ASEAN tentang Perlindungan dan Promosi Hak-Hak Pekerja Migran, namun upaya perumusan instrumen dari deklarasi tersebut mengalami kebuntuan karena adanya perbendaan kepentingan antara anggota ASEAN yang menjadi negara pengirim dan negara penerima pekerja migran.

Peran ASEAN dalam mempromosikan dan melindungi pekerja migran melalui pengadopsian deklarasi-deklarasi tersebut bukan merupakan suatu upaya dan peran yang optimal dan final. Tantangan kemudian adalah memastikan pelaksanaan yang efektif dari deklarasi-deklarasi tersebut dan memasukan nilai-nilai yang terkadung dalam deklarasideklarasi tersebut ke dalam mekanisme nasional di setiap negara anggota ASEAN. Memasukan nilai-nilai yang terkandung dalam deklarasideklarasi tersebut ke dalam mekanisme nasional di setiap negara anggota ASEAN merupakan keniscayaan demi efektifnya pelaksanaan dari deklarasi tersebut, namun dalam konteks perlindungan bagi pekerja migran, belum banyak yang dilakukan oleh negara-negara anggota ASEAN untuk melakukan tindakan dalam mekanisme hukum nasional negara anggota ASEAN berupa melakukan ratifikasi terhadap perjanjian internasional yang terkait dengan pekerja migran.

Sangat sedikitnya negara anggota ASEAN yang telah meratifikasi konvensi tersebut, menjadi salah satu sebab sulitnya tercipta konsensus di dalam penyusunan intrumen perlindungan dan pemajuan hak-hak pekerja migran. Namun demikian, terdapat alternatif terhadap kebuntuan konsensus penyusunan instrumen perlindungan HAM, yakni Indonesia dapat secara paralel dapat melakukan pendekatan secara bilateral dengan masingmasing negara penerima, sehingga akan lebih efektif dalam menyepakati penyelesaian permasalahan pekerja migran.

Selain itu, rekomendasi yang dapat dijalankan terhadap kebuntuan konsesus dalam penyusunan instrumen perlindungan dan pemajuan hak-hak pekerja migran adalah dengan membawa dan membahas isu tersebut ke dalam pertemuan Dewan Komunitas ASEAN, karena isu atau permasalahan pekerja migran merupakan isu lintas komunitas, karena terdapat unsur perlindungan dan bantuan hukum, unsur ekonomi dan sosial budaya, dan ketiga pilar komunitas tersebut membahas isu pekerja migran berdasarkan perspektif masingmasing pilar. 


\section{DAFTAR PUSTAKA}

\section{Buku}

ASEAN, ASEAN Economic Community Blueprint (Jakarta: ASEAN Secretariat, 2008).

ASEAN, ASEAN Political-Security Community Blueprint (Jakarta: ASEAN Secretariat, 2009).

ASEAN, ASEAN Socio-Cultural Community Blueprint (Jakarta: ASEAN Secretariat, 2009).

ASEAN, Repository Matrix of Legislations and Policies on Migrant Workers of ASEAN Member State (Jakarta, ASEAN Secretariat, 2012).

Direktorat Jenderal Kerja Sama ASEAN Kementerian Luar Negeri, Ayo Kita Kenali ASEAN (Jakarta: Kementerian Luar Negeri, 2011).

Human Rights Resource Centre, Rule of Law untuk Hak Asasi Manusia di Kawasan ASEAN: Studi Data Awal (Jakarta: HRRC, 2011).

International Human Right Clinic, The Protection of the Rights of Migrant Domestic Worker in a Country of Origin and a Country of Destination: Case Studies of The Philippines and Kuwait (Washington: International Law and Organizations Program and The Protection Project of The Johns Hopkins University Paul $\mathrm{H}$. Nitze School of Advanced International Studies (SAIS), 2013).

Kementerian Luar Negeri, ASEAN Selayang Pandang, Edisi ke-19 (Jakarta: Kementerian Luar Negeri, 2010).

Luhulima, C.P.F., ASEAN Menuju Postur Baru (Jakarta: CSIS, 1997).

Sulistyowati \& Shidarta (eds), Metode Penelitian Hukum: Konstelasi dan Refleksi (Jakarta: Yayasan Obor Indonesia, 2011).

\section{Jurnal / Prosiding / Hasil Penelitian}

Maloni, Bruno, "Migrant Workers in ASEAN" (makalah disampaikan pada ASEAN InterParliamentary Assembly, Seminar: The Role of Parliamentarians in The Protection and Promotion of the Rights of Migrant Workers in ASEAN, di Phnom Penh Kamboja, tanggal 3-6 April 2011).

Supriatna, Liona Nanang, "Piagam ASEAN : Menuju Pemajuan Dan Perlindungan HAM di Asia Tenggara" Jurnal Hukum Internasional, Vol. 5, No. 3 (April 2008).

Swajaya, Ngurah, "Promotion and Protection of Human Rights in the ASEAN Community Building : An Evolution Proces" (makalah disampaikan pada Panel Discussion on the ASEAN Community Building through the AHRD and the Phnom Penh Statement on the adoption of AHRD, as a joint event of the ASEAN CPR and AICHR, di Sekretariat ASEAN Jakarta, 23 Agustus 2013).

Tsani, Mohd. Burhan, "Arti Piagam Bagi ASEAN" (makalah disampaikan pada Pidato Pengukuhan Jabatan Guru Besar Pada Fakultas Hukum Universitas Gadjah Mada, tanggal 7 Mei 2008 di Yogyakarta).

Internet

"Komitmen Negara ASEAN Lindungi Pekerja Migran Diragukan" (http://www.hukumonline.com/ berita/baca/lt517fba0e98dfd/komitmennegara-asean-lindungi-pekerja-migrandiragukan, diakses 2 Juni 2014).

Dirjen Binapenta Ungkapkan Komitmen Ratifikasi Konvensi ILO No. 18", (http://www. solidaritasperempuan.org/dirjen-binapentaungkapkan-komitmen-ratifikasi-konvensi-ilono-189/, diakses 2 Juni 2014).

Kilas Balik Migrasi Lintas Batas Di Asia Tenggara, http://www.gugustugastrafficking.org/index. php?option=com_content \&view=article\&id=16 32:kilas-balik-migrasi-lintas-batas-di-asia-tengg ara\&catid=42: info\&/temid=66, diakses tanggal 3 Juni 2014

Migrant Care Anggap ASEAN Charter Tak Akui Hak Buruh Migran" http://www.tempo.co/read/ news/2007/11/20/059111962/Migrant-CareAnggap-ASEAN-Charter-Tak-Akui-Hak-BuruhMigran.

Sinapan Samydorai, "Is ASEAN Closer to Legal Protection of the Rights of Migrant Workers?", (http://aseanpeople.org/is-asean-closer-tolegal-protection-of-the-rights-of-migrantworkers/, diakses 2 Juni 2014).

United Nations Treaty Collection, https://treaties. un.org/, diakses tanggal 28 Juni 2014.

www.bnp2tki.go.id

\section{Peraturan}

Undang-Undang Nomor 39 Tahun 2004 tentang Penempatan dan Perlindungan Tenaga Kerja Indonesia di Luar Negeri. (Lembaran Negara Republik Indonesia Tahun 2004 Nomor 133. Tambahan Lembaran Negara Republik Indonesia Nomor 4445).

Undang-Undang Nomor 38 Tahun 2008 tentang Pengesahan Piagam Perhimpunan Bangsa- 